\title{
Emotion and moral purposes in higher education teaching: Poetic case examples of teacher experiences
}

Kathleen M. Quinlan, Centre for the Study of Higher Education, University of Kent, UELT Building, Canterbury, CT2 7NQ United Kingdom Email: K.M.Quinlan@kent.ac.uk

Paper accepted to Studies in Higher Education 26 March 2018. This pre-publication manuscript may differ slightly from the final, published paper:

Quinlan, Kathleen M. 2018. Emotion and moral purposes in higher education teaching: Poetic case examples of teacher experiences. Studies in Higher Education.

DOI:10.1080/03075079.2018.1458829

To link to the article: https://doi.org/10.1080/03075079.2018.1458829 


\title{
Emotion and moral purposes in higher education teaching: poetic case examples of teacher experiences
}

\author{
Although teaching is emotionally and ethically demanding, higher education \\ teachers' emotions, values and sense of moral purpose are under-researched. \\ This study examines 66 case examples of teachers' emotional experiences to see \\ whether and what kinds of moral concerns underpin those emotional moments. \\ Analysis was based on Graham, Nosek, Hadit, Iyer, \& Ditto's (2011) moral \\ foundations theory, which posits five main moral concerns: care/harm, \\ fairness/reciprocity, ingroup/loyalty, authority/respect, and purity/sanctity. \\ Care/harm and authority/respect were the most common single moral concerns \\ underpinning these emotional experiences, though there were examples of all five \\ moral concerns within the set. Approximately one third of the cases referenced \\ multiple moral concerns, suggesting the complexity of both emotional and ethical \\ demands in teaching. Implications for research, teaching and educational \\ development are highlighted.
}

Keywords: ethics, emotion, professionalism, faculty development, teacher identities

\section{Introduction}

'Teachers' emotions are inseparable from their moral purposes and their ability to achieve those purposes.' (Hargreaves 1998)

Hargreaves (1998) interviewed school teachers who spoke passionately about their love of children and their desire to create emotional climates that help students learn and grow. The teachers he studied were motivated by rewarding relationships with children. With a few exceptions (Noddings 2013; Goldstein, Liston and Garrison 2004), this moral imperative of working with young people and watching them grow has been neglected in teacher education and research on teachers (Martin 2004; Sutton 2007; Liljestrom, Roulston and deMarrais 2007). Recent studies of teachers' emotions (Liljestrom, Roulston and deMarrais 2007; Sutton 2007) and ethical dilemmas 
(Colnerud 2015; Shapira-Lishchinsky 2011), though, suggest that caring for children and protecting them from harm is a key moral concern of schoolteachers which, when thwarted, can trigger moral stress (Colnerud 2015).

Whether Hargreaves' assertion holds true in higher education may depend upon the extent to which those teaching in higher education identify as a teacher. Identifying with a teaching role involves emotional attachment to that role, which helps anchor who that person is and guides them in interpreting events and making meaning of their work and lives (Akkerman and Meijer 2011; Beauchamp and Thomas 2009). Yet, those new to teaching in higher education often struggle to create a sense of identity (Clegg 2008; Archer 2008), suggesting the need to provide additional professional development support to anchor new teachers in their role. Attention to moral concerns, then, could support identity development as teachers, which, in turn, affects both their professionalism and personal well-being.

As professionals, teachers in higher education have traditionally had the authority to make autonomous judgments under conditions of uncertainty that require balancing competing interests or principles. By definition, these situations involve ethical dilemmas (Shapira-Lishchinsky 2011). Fenwick ( 2016) argued that when faced with complex situations that defy simple rules, professionalism requires 'attunement' of ethical and emotional sensitivity, meaning an ability to interrogate external requirements and demands and integrate those with one's own personal moral concerns and commitments. Such attunement is a key goal in educating for professionalism (Fenwick 2016) and, with better understanding of the moral considerations in teaching in higher education, could be extended to professional development for teachers in higher education. Doing so would help bridge what Malcolm and Zukas ( 2001) called 
the 'pedagogic gap' in teaching and learning in higher education, by considering human and ethical dimensions, as well as technical ones.

Furthermore, researchers in moral psychology (Damon 2008; Damon and Colby 2015) have found that purpose, defined as a 'stable and generalized intention to accomplish something that is at the same time meaningful to the self and consequential for the world beyond the self' (p. 33) is vital to thriving in life. Damon and Colby (2015) found that individual moral commitments (ideals, purpose) are aspects of adult identity that are vital to sustaining moral action and ongoing moral growth.

What, then, are the moral purposes underpinning teaching in higher education? Macfarlane ( 2004) found that fairness, respect, and care commonly emerged as key concerns guiding moral reasoning when UK university teachers discussed case examples of ethical dilemmas related to teaching. Macfarlane's findings are consistent with an emphasis on concerns related to care and fairness found in literature in moral psychology (Graham et al. 2011), though his findings also highlight respect as a moral matter. The dilemmas that Macfarlane (2004) used, however, were generic with regard to subject matter, focusing on, for example, whether to grant extensions on course assignments, plagiarism, and acceptance of gifts.

Yet, many higher education teachers come to their profession because of identification with and love of their subject matter, rather than teaching per se. Disciplines have their own cultures, with their own ideas and embedded practices related to how teaching is conceived, understood and practiced. Teaching and learning regimes set out particular norms, values and ideas about what is (not) required, (in)appropriate, (un)acceptable and (il)legitimate (Trowler and Cooper 2002). Disciplinary values are also embedded in curricular standards (Quinlan 2016a). Close identification with the discipline, as well as greater authority over curricular decisions, 
may affect the moral concerns of teachers in higher education. Thus, some ethical dilemmas and moral imperatives faced in higher education may be more tightly linked with disciplinary values and debates than what has been discussed in the literature on primary and secondary school teachers.

Anna Neumann ( 2006) found that tenured professors in American research universities are deeply engaged with their subject matter, carrying powerful memories of early engagements with subjects that hold enduring fascination. They experience occasional peak moments of flow in working with their subject, described as exciting, exhilarating, obsessive and beautiful. She called this 'passionate thought.' These emotions are experienced in solitary scholarship or as a shared experience with colleagues and students. This finding suggests that research-heavy university teachers may have a moral purpose linked primarily to advancing knowledge in their fields, which may also underpin their emotions and moral concerns related to teaching Similarly, Åkerlind ( 2005) identified 'contributing to disciplinary growth or social change' (p. 21) as the most sophisticated conception of academic growth and development among Australian university teachers (working in research intensive universities). Furthermore, she found that part of being a teacher in higher education involves contributing to broader social change ( 2004). Both Neumann's ( 2006) and Åkerlind's ( 2005; 2004) findings suggest that moral concerns regarding teaching may be tightly bound up with the traditions and values of the disciplines being taught.

Western philosophy and findings in moral psychology consistently point to links between emotions and moral judgments, just as Hargreaves (1998) did in the opening quote. 'Emotions motivate or impel us to act morally' concluded Prinz and Nichols (2010, p. 5), although exactly how that process works and whether action is based on moral judgment and reasoning or simply intuition is disputed (Damon and Colby 2015). 
Beyond moral psychology, a frequently-cited theory of emotions in education (Pekrun et al. 2007) holds that the value an individual places on something is a key determinant of the emotion generated. In other words, if you value (i.e. care about) an activity or an outcome, your emotions will be primed. If you don't care about it, little emotion is aroused. Thus, by looking closely at emotional episodes, one should be able to infer the individual's underlying values.

Given the importance of emotion to moral action (Prinz and Nichols 2010) and to values more generally, this study examines emotional episodes in teaching in order to illuminate the underlying moral concerns of higher education teachers. The key question is: what moral concerns are embedded in emotional experiences of higher education teaching? In particular, I seek to identify the range of moral concerns underpinning emotional episodes in higher education teaching and how this plays out in teachers' practices. This range is hypothesised to involve concerns related to curriculum and the representation of the discipline itself.

\section{Conceptual framework}

I use moral foundations theory (Graham et al. 2011) to examine the moral concerns that underpin teaching in higher education. The theory defines a moral system as, 'an interlocking set of values, virtues, norms, practices and identities, institutions, technologies and evolved psychological mechanisms that work together to suppress or regulate selfishness and make social life possible' (p. 368).

Moral foundations theory was developed based on a review of cross-cultural literatures and focused on theoretical ideas with a basis in evolutionary thinking (Haidt and Joseph 2007). These theorists took issue with narrow definitions of the moral domain that have dominated moral psychology, such as Turiel's ( 1983) seminal 
definition of morality: 'prescriptive judgments of justice, rights, and welfare pertaining to how people ought to relate to each other. Moral prescriptions are not relative to the social context, nor are they defined by it' (p. 3). Joseph and Haidt ( 2007) disputed this a priori exclusion of social conventions from the moral domain, arguing 'It would be a gross misunderstanding of ancient Judaism, for example, to describe the Ten Commandments as a mixture of moral rules (about not stealing, killing, or lying) and social conventions (about the Sabbath, and prescribed ways of speaking and worshipping)' (p. 372). As cultural psychologists, they are rooted in ethnographic accounts of morality from a variety of cultures. They 'take as given (at least at the beginning of analysis) that what people think are their moral concepts are, in fact, moral concepts - rather than dividing them into "moral" and "conventional" concepts at the outset' (Haidt and Joseph 2007).

By taking a bottom-up, cultural view, their research yielded five sets of moral concerns: harm/care, fairness/reciprocity, ingroup/loyalty, authority/respect, and purity/sanctity. Harm/care refers to avoiding harm to other people. Fairness/reciprocity refers to ensuring fair/just treatment for all. Ingroup/loyalty refers to protecting social institutions of family, community, and country (and other ingroups) and embraces an ethic of community. Authority/respect refers to duty, obedience, and preservation of tradition, particularly in the fulfilment of role hierarchies. Purity/sanctity refers to adherence to religious norms and standards of decency, chastity or natural laws, even if a violation (e.g. a private sexual act between consenting adults) does no harm to others (Graham et al. 2011). These concerns are considered universally available, but are developed to varying degrees in different cultures and contexts. These five foundations build upon several other taxonomies of moral concern and were tested against those 
models in an analysis of their Moral Foundations Questionnaire, demonstrating the validity of their five factor model (Graham et al. 2011).

A major contribution of the theory is to expand the definition of moral concerns typically pursued by moral philosophers, psychologists and educators. Their theory expands research attention to include questions about ingroup/loyalty, authority/respect, and purity/sanctity as part of the moral realm (Graham et al. 2011). Further attention to authority/respect and ingroup/loyalty concerns may be particularly important in capturing the social norms of particular disciplines (Trowler and Cooper 2002) as well as to equality, diversity and inclusion agendas in higher education. Furthermore, teaching is an activity that places teachers as an authority (being knowledgeable) and in authority (responsible for directing others' activities) in relation to less powerful students, thus authority/respect concerns are likely to be central to teaching (Buzzelli and Johnston 2001).

\section{Method}

I analyzed a subset of case examples $(n=66)$ drawn from a larger project (Quinlan 2016b) that captured the emotional experiences of teaching or learning in higher education through 138 case examples written as poems. Those poems were printed in full in my earlier book (Quinlan 2016b) and organised into thematic chapters with associated expert commentaries. In that larger project, poems were solicited through classified advertisements for writers and through various creative writing networks in the UK, UK, Canada, Australia and South Africa between December 2013 and April 2014. Poems that captured the felt experience of teaching or learning in higher education and that addressed the selection criteria described below were sought. 
The solicitation welcomed previously published and new, unpublished poems from living poets with experience as a student or teacher in higher education, capturing poems written at various points over the past 25 years or so. The original date of writing (or the date of the event that inspired the poem) was not collected. Poems were used as source materials because they are emotionally evocative (Padel, 2002), allowing the features of the genre to further illuminate the object of study. Because poems are also short, many people were able to contribute directly in their own words.

This larger project was inspired by poetic inquiry (Prendergast 2009) and methods in communication studies (Pelias 2004). Researchers in higher education have a highly literate and articulate group of colleagues (some of whom are poets) who can describe the felt and lived experience of higher education, enabling a reframing of the relationship between researcher and researched. Thus, poets-who-are-also-highereducation-teachers became collaborators/contributors writing reflectively in their own ways, rather than subjects or participants (Quinlan 2016b). Poets gave formal consent for the use of their poems in the book. Poets quoted here were emailed this manuscript and offered the opportunity to comment or opt out.

Poems were selected based on 4 criteria: 1$)$ poetic sensibility such as ability to engage the reader, aesthetic and rhythmic qualities, and imaginative use of language; 2) credibility in capturing an important truth and based on lived experience - either their own or someone else's; 3) saying something important to the theme of emotions in learning or teaching in higher education; 4) accessibility and clarity to audiences unaccustomed to reading poetry. Poets could submit a commentary (up to 100 words) about the inspiration for their poem to help international readers understand the context, focus, or motivation for the poem. Many did so. As a published poet and educational development specialist, I read each submitted poem multiple times to select those for 
inclusion. The selection method, therefore, relied upon expert judgment (Eisner 2017). For more details, see Quinlan (2016b).

These inclusion criteria map well onto criteria for assessing the validity of qualitative research (Altheide and Johnson 1994) including plausibility, credibility (my criterion 2), relevance and importance of the topic (my criterion 3) and reflective accountability. Reflective accountability refers to attentiveness to the process of the work, including relationships between what is observed and larger contexts (the poet's commentary), point of view and interpretation, and the role of the reader through issues of style (my criteria 1 and 4$)$.

In this study, I only analyse poems written from a teacher's point of view, which included 66 poems written by 46 different people. The majority ( $n=33$ or $72 \%$ ) of poets were women. Although the cases were solicited broadly within poetry communities in English speaking countries (US, UK, Canada, Australia), most of the poets included in this study were situated in the US higher education context ( $\mathrm{n}=38$ or $83 \%)$, including community colleges, liberal arts colleges and state universities. Of the remainder, four $(9 \%)$ were based in Canada, three $(6 \%)$ in the UK and one (2\%) in Australia. Most poets taught English or liberal arts ( $\mathrm{n}=35$ or $76 \%)$, though some of the scenarios occurred during individual interactions with students where the discipline did not feature in the case example. The subjects taught by five of the poets were not discernible (11\%), three were in math (6\%), one was in psychology $(2 \%)$, and one was in communications $(2 \%)$. This prevalence of literature teachers reflects the sampling strategy (seeking poems through established poetry communities), given that teaching literature and writing is related to being a poet. Thus conclusions about the frequency of moral concerns (or emotions) in different disciplines, or the types of moral concerns found in teaching various disciplines, cannot be made. Nonetheless, this study provides 
an important 'proof of concept' for the existence of a wider range of moral concerns experienced by teachers than has been previously discussed. It also demonstrates the utility of extending moral foundations theory to the domain of teaching in higher education, offering both a new application of that theory and a new theoretical lens on teaching in higher education.

For this secondary analysis, I act as curator of the larger collection. Curating is a method (Puwar and Sharma 2012) drawn from the visual arts that emphasises interpreting, translating, and mediating between objects and artists and new audiences (Balzer 2014). The curatorial 'eye' involved multiple close readings, re-arranging poems by reading them in different groupings to expose new meanings, as well as reading through the lenses of different theories. In this study, I analysed the poems and associated commentaries through the theoretical lens of moral foundations theory (Graham et al. 2011) to identify the underlying moral concerns reflected in each poem. I grouped (and re-grouped) the poems according to the main constructs in the theory, seeking subthemes within key theoretical constructs. Whole poems were labelled according to which moral concerns they addressed; each poem could address multiple concerns. While poems, by their nature, defy a single interpretation, the clarity and accessibility of these poems, together with the poets' commentaries enabled me to see how poems could be argued as illustrating one or more of the five moral concerns in the moral foundations theory (Graham et al. 2011).

In the results section, I present examples highlighting how a given moral concern manifests itself in teaching in higher education. I reference the selected poems by author and title and page number of where they appear in the original book (Quinlan 2016b). Thus the reader can access the original source material for their own 
interpretation. Direct quotes capture the flavour of the cases and illustrate my interpretation.

\section{Results}

Of the 66 cases analysed, nearly half of them spoke primarily to a single one of the five moral concerns. I found all five concerns illustrated in the set. A large subset (nearly one third) seem to address two or three moral concerns, suggesting the complexity of real-world moral concerns. The most common combination focuses on both authority/respect and ingroup/loyalty, such as when a minority teacher's authority is challenged or respect isn't shown to their "ingroup". Care/harm is also frequently combined with another moral concern such as purity/sanctity, fairness/reciprocity, or ingroup/loyalty. Some 18 poems (27\%), though, did not point clearly to any of the five moral concerns in the theory.

In this section, I present examples of each of the five moral concerns with quotes from exemplar poems ( '/' denotes line breaks). Under each moral concern, I show how it is combined with other concerns within this sample. I also include a subsection that analyses poems with no obvious connection to Graham and colleagues' (2011) moral foundations theoretical framework.

\section{Care/Harm}

Many of the poems in the set deal with care/harm. These case examples include situations in which students had personal crises, including abortions, rape, break-ups with romantic partners, negotiating sexual, racial and ethnic identity, family conflicts, 
and suicide. These often intersected with other moral concerns such as purity (rape, selfharm, suicide) or with ingroup/loyalty (identity development).

In an example that touches on both caring and ingroup loyalty, Terry Martin (The Third Wrestler Cries, p. 88) writes about Jaime, a 'freshman coiled tight as a spring...wanting/ to talk about the Sherman Alexie poem/he has chosen for his class presentation ...When he reaches a line that moves him, lips tremble and he halts, unable to continue./...see, I get this guy he tells me, voice cracking.' The narrator empathises with Jaime, '...I get you, too./ See, I know about intensity.../Know the pressure of oneon-one, how it feels to be alone out there...' In the accompanying commentary, Martin writes, 'So much of what's interesting, and exhausting, about working in higher education happens outside the classroom. This poem is one of a series exploring the teaching that happens one-on-one, during office hours, which may be some of the most important work we do.'

Some students simply need the reinforcement and recognition that a caring teacher can offer. Suzanne Roberts (Night Class, p. 84) reflects on a night class in writing that she, 'dreads, somebody/always wanting something.' In particular, she tries to escape an older student 'with worn spidery skin,/... a Band-Aid stretched across her nose. Always/coughing, saying Sorry, coughing again./Always asking me to proofread her résumé, poems, the children's story she'd written with her shaky hand.' Despite the narrator's admission that the neediness of students is burdensome, the poem ends with a realisation of the importance of this extra help and care. An assignment to write a thank you note, 'to the person/who has been the greatest help of all' is addressed to the teacher herself, 'the shaky hand/claims there is nobody else.'

In another poem, we see the healing, rather than draining, effect of the caring relationship on the teacher as it can play out in whole class interactions. Joann Gardner 
(Modern Poetry, p. 96) describes the undergraduate students in a class session on Walt Whitman in vivid detail, with their 'alpaca hats...all in love with themselves/and bristling with personality.' The narrator is 'fresh from a season of loss and uncertain what/I'm here for.' But as the students and teacher talk, 'the room begins to stir...Gradually,/I come alive, respond to their instruction... They tease me/ back into the room, back from my brooding sorrow/to the head of the class, saying, "You are/the teacher. Teach us."' In this poem, the narrator cares about her students, illustrated by her affectionate descriptions of them. Through interaction, she reconnects with her purpose as a teacher so that she 'comes alive.' Caring in teaching not only touches students, but also has the potential to nurture teachers.

While many of these 'care' examples take place in interpersonal conversations outside of class time ('office hours'), some deal with these issues as they arise in the classroom situation. The moral question grappled with in two striking examples of classroom situations was when to alter one's plans for a given lesson to allow time to process bigger emotional or moral concerns. For example, Suzanne Roberts in 'When to Pause' (p. 108) writes about a fatal accident involving one of the students in the class and the roommate of one of her students. The narrator writes, 'I continue with the rules/for the comma/and the dead boy's/roommate takes notes.'

Two poems explicitly deal with attempting to teach (or preserve) students' caring for others. For example, in 'Lesson of the Day' (p. 115), Bunkong Tuon, a Cambodian Genocide survivor who assigns his students a book on the Cambodia Genocide responds to students' interpretations of the book: 'If we take/away the comforts of civilization,/aren't we just animals?' Tuon replies by telling his own story and exhorts the students, 'Listen,/ I wouldn't be standing in front of you/if it weren't for the love of my uncles,/aunts, and grandmother. Have faith/in the love of ordinary 
people.' In his commentary, he writes that he, 'explores difficult topics (such as war, hunger, genocide, and racism) in my classes...I remind students of the goodness in humanity.' In this example, 'care' becomes the curriculum itself.

\section{Authority/respect}

Many of the poems also deal with authority/respect, illustrating struggles with whether to follow or reject rules and traditions. In an extreme example, Bonnie S. Kaplan ('Talking Ban' p. 139) is teaching in a rehabilitation unit in which, 'Residents are not to engage in any discussion with the opposite sex.' She chooses not to enforce the talking ban, 'If Antonio wants to help Marquita/ better understand the Barbarian takeover/ of the Roman Empire,/ then more power to that.' While few teachers face this kind of ban, they may work under a variety of other institutional rules (no food/drink allowed; lecture-capture technologies; attendance monitoring) that they may choose to enforce or not.

Similarly, pedagogical traditions may be accepted or challenged. For instance, several of these poems explore clashes in values between colleagues about the subject itself. In 'Teaching Observation (p. 229), Marion Deutsche Cohen was told by the observer not to spend so much time telling the students 'how wonderful it all is', when she wanted to stimulate interest and excitement in the mathematics (her subject) by highlighting the beauty of the subject. Janet McCann's narrator (No, p. 158) objects to the way in which a visiting professor, 'tells my class/this is what the poem means/'. Instead, she wants to say 'No, it does not mean that.' The teacher does not object to the particular interpretation so much as presenting it as a conclusion, 'doors slamming/down the hallway of his voice.' Instead, she prefers to allow a variety of interpretations to flourish: 'no, no the poem spills out/of this hall..." The poet seems to 
argue that authority lies in the poem itself, not in a single academic's interpretation of it. To respect the poem is to let it 'spill out', because after all is said and done, 'all/that will be left will be poem'.

Similarly, in 'The Canon' (p. 175), Joyce Kessel argues for an expansion of the traditional literary canon of 'solid, classic names' and 'redundant bios', ‘...I now people my choices/with women and writers of all shapes, colors/and preferences,/always believing that genre \& gender, can share...the same pages.' Here the questions of authority lie not just in how a subject is taught, but what constitutes the subject itself.

Teachers also struggle with finding their own personal authority in the classroom, which may be more difficult for teachers who are in some way different from their students. Nina Pick's (School of Embodied Poetics, p. 179) narrator worries, 'When I first started teaching, I thought/my students could see my heart on my sleeve...I felt embarrassed to have such a/visible heart;... It seemed none of my students/had a heart like mine...' She seeks advice from a supervisor who says, “'Well, the best you can be is a role model. Maybe they've never had the chance/ to learn about the heart. Try teaching it/ the same way you teach grammar."/So I went back to class, and returned to/the living pulse of the text...' In time, 'my heart led an/orchestra of small flowers.' Here, the narrator gains a greater sense of authority and, by embracing her own identity authentically, gains both self-respect and the respect of students who join her in drumming 'the heartbeats of the iambs' on their desks (Note: An iamb is a rhythmic unit in poetry consisting of two syllables in which, like a heartbeat, the first syllable is short or unstressed and the second is long or stressed.

Other poems explore common performance anxieties. For instance, April Selley (Professor's Anxiety Dreams, p. 225) offers examples of the various forms that anxiety dreams take. Underneath them all are worries about authority and lack of preparedness. 
It begins with a dream about 'teaching a class that an American Literature professor can't fake. This time, it is Calculus' and romps through failing to have taken a required class, running late, having no course materials, being unable to "see, or speak, or hear...or read my notes...or write words on the board.' or students who are 'resentful', unwilling to participate or 'hissing about my incompetence'.

\section{In-group/loyalty}

Several poems illustrate how teachers deal with difference - their own and that of their students. At times, there are dilemmas of loyalty to one's own in-group and concerns about how much of themselves to reveal to students, particularly if the teacher identifies with a minority group. Penelope Dane (Low Level, p. 119) writes in her commentary, 'In seven years of teaching in the English department at Louisiana State University, I did not invite a queer student panel to speak in my class because I was afraid that I would make myself too vulnerable. If my students were rude to the panel, I worried my own emotional response would out me.' In fact, her poem explores what happened when she did, eventually, invite a queer student panel. '...most of section 56 focused, except/the Christian frat boy in the front row/who radiated fear as the scratched/letters into a crossword puzzle...erased/so hard his desk squeaked.' The student panel carried on answering questions, though 'twisting their fingers' and she writes, 'I regret I waited/until after class to confront/him about the crossword puzzle'. In a similar scenario, the white narrator in Bridget Dixon's 'No Offense' (p. 128), struggles to suppress her emotional reaction when a black student 'fires the phrase' "“No offense/but I can't stand white people"” across the classroom at her.

Carolyn Martin, a former Roman Catholic Sister of Mercy, (8'O Clock Monday Morning, p. 93) digresses into reciting a poem of her own while teaching. When the 
students demand to know who wrote that poem, she regrets the 'breach', wondering 'What can I say when decades separate/ our lives? How [do I] help them understand/ a woman in a short black veil/...desires love as much as they? How to explain passions denied harden/into icy pain?' In these examples, the teachers feel their category of difference strongly and experience it as a barrier to connection with students.

Other teachers tend to focus on students' responses to the subject, rather than ethnic, religious, racial, or sexual orientations they embody. For instance, Daniel Scott Tysdal (I Wear a Hijab (Lol), or Professor Puts a Cupcake in the Fridge, p. 113) challenges the categories by which students choose to describe themselves. In his commentary, he writes 'I received an email from a former student looking for a letter of reference. To refresh my memory, she wrote, "I wear a hijab (lol)." I experience a huge contrast between what the student thought I remembered and what I remember about her...' In the poem, he writes 'what I remember/is the story you wrote about your trip to the country where your parents were born,/the last line bearing a rooftop in rain,/and you in that rain once, for real, and me/feeling it in your words, the full, wet fall.' The student is remembered as a vivid writer with a rich story.

\section{Fairness/reciprocity}

Relatively few cases deal exclusively with fairness. In one clear situation, Joy Reid's (Accused, p. 87) narrator stands before two accused students, playing the role of judge in a case of wrongdoing. She describes each girl, 'one seems genuine' and the other 'her insincere sincerity and scapegoat eyes/disturb'. With each, the teacher asks herself, 'Could it be her?' and goes on, 'If I could separate/yolk/from white/my decision would be golden - but truth is scrambled.' Although higher education teachers may not often arbitrate between two students to determine who is telling the truth, there are many

18. 
instances in which students make special requests (e.g. for extensions), that may pose issues of fairness.

These poets combine concern with unfairness with their care for students. They are saddened when they see students grappling with injustices in life. In Gail Griffin's poem, 'Mary Alice' (p. 64), the teacher empathises with a student whose heart is broken 'when someone doesn't love you back, or in the same way, or something...And as we sit in silence...I realize there's absolutely nothing to be said to you. Yes. Sometimes we are not loved back. It's the primal injustice.'

Another teacher also counsels a student confronting more generalised injustice in the world. June Sylvester Saraceno (Chrysanthemums and the Communist Manifesto, p. 148) offers her student, 'a book whose illicit pages held/a rusty key I needed once/...I hand you what I have:... The world may stink and no easy way to fix it/but words ripen in the mind.' In her commentary she explains that the poem was written for a student, 'who struggled with how to respond to the injustices in the world that seemed overwhelming to her. Literature was a way for us to talk about this and it offered her various perspectives.' In these situations, it is less about the teacher needing to decide what is fair and more about being challenged to support students who either personally experience unfair situations or are coming to terms with injustice in the world.

Fairness is also bound up with concerns about authority. For instance, Shinelle L. Espaillat (Comp and Circumstance, p. 58) writes in her commentary that she, 'finds that the need to evolve and adapt pedagogical strategies can conflict with agendas held by administration, parents... and often the students themselves. I constantly learn to rebalance the real needs within the classroom and within the administrative system, in addition to my own needs as an educator and person.' This balancing of needs and priorities plays itself out in systems of marking. In the poem she wonders, 'how to read, 
one more time,/ every paper Silent Girl submitted,/ knowing it is time to pick up a pen/and press its point through the thin skin/of dreams this girl barely dares to hold,/'.

Similarly, in Elizabeth Bradfield's 'Distance Education' (p. 144), a teacher wonders how to teach a mandatory course to indigenous teachers' aides who live in a very different context. Charged with teaching punctuation, she, 'assigns homework they don't do/because they had to take kids away from fathers or because/cloudberries ripened in the bog.' In her final line, looking at her spreadsheet of work done, 'I fail them' has a double, ambiguous meaning. By insisting on mainstream standards (correct punctuation), they would receive failing grades. And by insisting on mainstream standards, she fails to pay enough attention to the 'stories/they tell themselves to make it [formal English] matter.' She questions what it is to serve these students and what is most fair to them, their communities, and the children in their care.

\section{Purity/Sanctity}

Several poems illustrate ways in which teachers may experience some situations as sacred or as violations of purity. Noel Sloboda (College Open House, p. 252) is concerned when the sanctity of academic subjects is defiled as administrators sought teachers to give 'sexy presentations' to prospective students. Although the earlier exploration of authority/respect showed disputes over what counts as knowledge (e.g. 'The Canon') and how best to teach students, the strength and consistency of language in this poem suggests more than a question of bowing (or not) to disciplinary traditions. Explicit comparison to bloody rituals situates this as a clear corruption of pure academic knowledge. 'All over/ the floor lies literature/from academic programs,/like entrails spilled -/a pagan ritual...' Even the descriptions of people are meant to evoke disgust, 
'bloated bellies/... sway and jiggle,/each like a bag/full of unwanted kittens/dropped in a river'.

Carol Tyx (The Pleasures of Teaching Emily Dickinson, p. 182) also invokes sanctity as she likens teaching an Emily Dickinson poem to receiving Communion, 'there's a sacramental quality to receiving an Emily Dickinson poem: all we need is a bit of bread - a crumb dipped in the wine of metaphor - and it becomes a whole load, a risen body.' These religious metaphors situate this experience as something sacred.

In another example, a student's behaviour defiles his/her own purity. In Suzanne Roberts' (Connection, p. 85) the narrator is horrified that a 'beautiful' female student identified herself with a poem about 'a young girl/who learns to hate/herself, cuts off/her nose and her legs,/offers them up'. The sense of disgust at bodily mutilation is the central theme. Other poems also combine a sense of caring for students with concerns about purity and sanctity.

\section{Emotional episodes with no obvious, underlying 'moral concern'}

To explore Hargreaves' assertion that, 'Teachers' emotions are inseparable from their moral purposes and their ability to achieve those purposes' (1998, p. 838), this section explores those episodes that have emotional dimensions, but do not obviously exemplify any of the five moral concerns in the moral foundations theory.

There is considerable variability in this set of poems, though most of them are positive and light-hearted. For instance, Susan Carol Hauser (Destination, p. 97) describes taking her students outside on a sunny autumn day, 'too fine for lessons. 'It pleases me to see them leaning into their work,/ resisting the breeze that is too brisk for our purpose'. In the migrating geese, she sees her own students who, 'will leave one day, flapping awkwardly/ out of and toward their destinies,/' and sees herself also 
leaving one day, 'squawking like an old hen/deprived of her nest, uncertain of my certain destination.' While this suggests fond feelings for her students, it recognises them as independent, rather than emphasising that they need care. Joyce Kessel (Teaching Poetry, p. 172) also delights in the 'buzz' of her students with their 'heads bent, creating'.

Three poems take a playful take on grading. As such, they evoke laughter, without necessarily invoking deeper moral concerns. One could argue that by poking fun at authority, these poems are a form of resistance to regimes of assessment, but their playful tone belies such a serious interpretation. For example, in 'Answers May Vary' (p. 224) Sandra McRae puts a 'test' on the projector a week before final exams that asks absurd questions, such as ' 2 . If the square root of pain is being wrong, what is the cosine of being annoying.' and ' 6 . Justify your life.' In her commentary, she writes, 'I think it is important to make learning fun. It was the week before finals when I put this on the projector screen. My students blanched. They were so relieved when I told them, "today we're going to talk about parody." There are no moral quandries here, just an injection of fun. Thus we see a value, but not a moral one.

Other poems comment on the pleasure of particular subjects. Eveline Pye (Love of Algebra, p. 193) wonders, 'How could I ever not know how to solve/simultaneous equations?/It would be like forgetting how to breathe or laugh or love.' While similar to the Carol Tyx poem discussed under the theme of purity and sanctity above, Pye's poem evokes emotion without foregrounding purity or sanctity concerns. If one takes a broader view of moral purpose as caring about the subject and students' engagement with the subject, then the teacher's pleasure in these instances could be seen as stemming from the value they place on what Neumann (2009) called 'passionate thought.' 


\section{Discussion}

Although teaching is a moral enterprise, there has been little research on the moral imperatives or moral demands on teachers in higher education. This study applies Graham and colleagues' moral foundations theory (Graham et al. 2011; Haidt and Joseph 2007) to a substantial set of cases of teaching in higher education. Twenty-six poems (by 24 authors) are referenced in the results section.

As these case examples were solicited and selected for how they represent a range of emotions experienced in connection with teaching (not moral issues), the large percentage of cases that capture moral issues highlights the connection between emotions and moral concerns. This study contains examples of all five of Graham et al's (2011) moral concerns, a theory of moral concerns that is intended to broaden moral discourses to a wider range of issues. Thus, it also offers proof-of-concept for a wider range of moral concerns in higher education teaching than highlighted in extant literature. Those poems that did not fit neatly into this theory suggest values such as fun, creativity and aesthetic appreciation, as well as corroboration of Neumann's (2009) 'passionate thought' as a key value in higher education teaching.

Concern with care/harm is consistent with its dominance in general literature on morality (Haidt and Joseph 2007), as well as existing moral education literature in primary or secondary education (Noddings 2013; Liston and Garrison 2004; Colnerud 2015; Shapira-Lishchinsky 2011) and in higher education (Macfarlane, 2004). Through this study, we see how the moral concern of care can play out in individual pastoral care and how care is enacted through teaching of particular subjects in particular ways. Discussion of literature, for example, provides opportunities to become impassioned, to 'lose yourself in what you are do/in hopes of finding yourself.' (Terry Martin, The 
Third Wrestler Cries, p. 88) and to explore fundamental life lessons such as faith in 'the love of ordinary people.' (Bunkong Tuon, Lesson of the Day, p. 115). Teacher-student relationships are vital to student learning, a key part of developing an identity as a teacher (van Lankveld et al. 2017), and often the root of distressing emotions in teachers (Lahtinen 2008). Dilemmas in practice arise when deciding what is in the best interests of an individual student or a group of students (Scager et al. 2017). Therefore, higher education teacher development programmes could focus more explicitly on relationships with students, pastoral care responsibilities, how teachers can teach about caring (Noddings 2013), and the dilemmas that can arise when trying to act in the best interests of students.

Existing philosophical and psychological literature also focuses heavily on concerns of fairness/reciprocity. In this study, though, there were relatively few instances in which fairness was the sole concern. Instead, concerns with fairness were frequently intermingled with concerns about either care/harm or ingroup/loyalty. These suggest the potential complexity of 'fairness' in higher education, both as a part of the curriculum itself (e.g. making sense of injustice) and in enacting policies surrounding equality and diversity. Given increasing student diversity in most Anglophone countries, teachers would benefit from discussing what constitutes fairness (e.g. equity versus equality) within broader social situations of injustice and inequality.

This study also highlights concerns about authority/respect and ingroups/loyalty, both of which are aspects of moral concern that moral foundation theory opens up. A teacher's authority is the basis on which they are able to authentically model a set of values or fulfil their sense of purpose, making it central to teacher development (Clegg 2008; van Lankveld et al. 2017). When that authority is questioned, teachers may experience anxiety, anger, or frustration - and must choose whether and how to persist. 
Being authentic also involves identifying with groups (e.g. racial, ethnic, religious, sex/gender) to which one belongs, acknowledging those aspects of one's identity, and choosing how to embody, represent or model those loyalties. These are key questions for new teachers - particularly those from underrepresented minorities - as they gain confidence in their teaching roles. These poems offer prompts for discussing how teachers present themselves to students.

As it is the nature of poems to highlight poignant moments, these examples may capture unusual moments (death, students crying, a dramatic classroom episode). However, by analysing these cases as instances of broader, theoretical constructs, they gain generalisability (Yin 2013) and invite the reader to consider other ways in which the moral concern may manifest itself in their own setting. Further research is needed to understand how common these concerns are, how widespread they are (across disciplines, countries, institutional types, and teachers of varying levels of experience) and their salience in teachers' day-to-day decision-making. Nonetheless, this study has mapped an expanded terrain and raised questions about the link between moral concerns and emotions. It demonstrates the application of a conceptual framework that can guide further study of higher education teachers' moral concerns. This framework is broader than those used in existing studies of school teachers' ethical dilemmas, which may make it more suitable for investigating higher education teaching where teachers have more autonomy over the curriculum and identities more closely tied to their discipline and its traditions.

In addition to forming a foundation for future research in a nascent field, this study may also support initial and continuing teacher development in higher education. In the UK and Northern Europe, for instance, higher education teacher development programmes are well established and serve as the benchmark for other European 
countries that are expanding their own teacher development provision (Pleschova et al. 2013). Some countries, such as Denmark and Sweden, require that new teachers in higher education participate in a substantial, formal programme as a condition of probation. Most UK universities require probationary (untenured) teachers to gain teaching certification, often through completion of a graduate level programme that includes reading, class discussion, and formal assessment.

In the UK, the UK Professional Standards Framework is a key accreditation standard for nationally recognised teaching qualifications in higher education. It specifies four key values that teachers are expected to demonstrate (Higher Education Academy 2011). Although accredited programmes must teach to those values, few teaching resources exist to support teachers in examining their own values or moral concerns as teachers.

The poems referenced in this study can serve as case examples for discussion, opening up a wider range of moral concerns for reflection and discussion. The full text of the poems can be found in (Quinlan 2016b), together with a discussion guide for use in facilitating workshops on emotions in teaching. A workshop facilitator might present the moral foundations framework and ask teachers to analyse the poems (or participantor facilitator-generated examples) using those moral concerns. The case examples highlight common intersections between foundational moral concerns (and, thus, moral dilemmas) that higher education teachers may confront. In fact, some of the moral concerns in this framework are set up as a dialogue; authority/respect, for example, suggests a tension between tradition and innovation. Discussions of case examples that capture real life situations that defy simple rules are recommended for preparing new professionals for ethical dilemmas they may encounter in practice (Fenwick 2016). 
Broadening the range of moral concerns helps teachers see multiple values at play in a given situation. The theoretical framework provides a moral language and categories of moral concerns to help participating teachers make their implicit assumptions explicit, which can be helpful in articulating their goals, writing statements of teaching philosophies, or analysing stressful situations they may encounter in their day-to-day lives as teachers. Explicitly discussing moral concerns and competing values opens them up to critique and to alternative ways of framing the issue, and, thus, other courses of action.

In some countries, including in the US, teacher development workshops may be more ad-hoc, and few higher education teachers will have systematic training in teaching. These poems can also be used in one-off faculty development workshops to highlight overlooked aspects of the experiences of higher education teachers. Given that teachers experience moral stress when their moral purposes are thwarted (Colnerud 2015), these cases may be particularly valuable during times of organisational or social change when changes in policies or priorities may conflict with teachers' own sense of purpose. Developing and reinforcing teachers' identities can help sustain them when the environment may be less supportive (Damon and Colby 2015).

In sum, investigating intersections among competing moral concerns may be particularly fruitful in rethinking both research and practice. Further research could focus on caring for students' welfare, how to wield authority responsibly, and how to manage one's own relationship to one's in-groups. Teacher development workshops also can be based around the examples and framework highlighted here.

\section{Acknowledgements}


I am grateful to the poets for their participation in the larger project and permission for their poems to be discussed and quoted in this manuscript. I also thank three anonymous reviewers for their helpful comments on an earlier version of this manuscript.

\section{References}

Akerlind, G. S. (2005). Academic growth and development-How do university academics experience it?. Higher Education [Online], 50(1), 1-32.

Akerlind, G. S. (2004). A new dimension to understanding university teaching. Teaching in Higher Education [Online], 9(3), 363-375.

Akkerman, S. F. and Meijer, P. C. (2011). A dialogical approach to conceptualizing teacher identity. Teaching and Teacher Education [Online], 27(2), 308-319.

Altheide, D. L. and Johnson, J. M. (1994). Criteria for assessing interpretive validity in qualitative research. In: Denzin, N. K. and Y. S. Lincoln, Y. S. eds. Handbook of Qualitative Research. [Online]. Newbury Park, CA: Sage Publications, Inc, pp. 485-499.

Archer, L. (2008). Younger academics' constructions of authenticity and success" and professional identity. Studies in Higher Education [Online], 33(4), 385-403.

Balzer, D. (2014). Curationism: How Curating Took Over the Art World and Everything Else. [Online]. Toronto: Coach House Books.

Beauchamp, C. and Thomas, L. (2009). Understanding teacher identity: An overview of issues in the literature and implications for teacher education. Cambridge Journal of Education [Online], 39(2), 175-189.

Buzzelli, C. and Johnston, B. (2001). Authority, power, and morality in classroom discourse. Teaching and Teacher Education [Online], 17(8), 873-884.

Clegg, S. (2008). Academic identities under threat?. British Educational Research Journal [Online], 34(3), 329-345.

Colnerud, G. (2015). Moral stress in teaching practice. Teachers \& Teaching [Online], 21(3), 346-360. Available from:

http://search.ebscohost.com/login.aspx?direct=true\&db=bri\&AN=100953736\&site =ehost-live.

Damon, W. (2008). The path to purpose. [Online]. New York: Free Press.

Damon, W. and Colby, A. (2015). The Power of Ideals: The Real Story of Moral Choice. [Online]. Oxford: Oxford University Press. 
Eisner, E. W. (2017). The Enlightened Eye: Qualitative Inquiry and the Enhancement of Educational Practice. [Online]. New York: Teachers College Press.

Fenwick, T. (2016). Professional Responsibility and Professionalism: A Sociomaterial Examination. [Online]. Abingdon: Routledge.

Goldstein, L. S., Liston, D. and Garrison, J. (2004). Loving teacher education. In: Liston, D. and Garrison, J. eds. Teaching, Learning and Loving: Reclaiming Passion in Educational Practice. [Online]. London, UK: RoutledgeFalmer, pp. 3547.

Graham, J., et al. (2011). Mapping the moral domain. Journal of Personality and Social Psychology [Online], 101(2), 366-385.

Haidt, J. and Joseph, C. (2007). The moral mind: How five sets of innate intuitions guide the development of many culture-specific virtues, and perhaps even modules. In: Carruthers, P., Laurence, S. and Stich, S. eds. the Innate Mind, Vol. 3.Â. [Online]. Vol. 3. New York: Oxford University Press, pp. 367-391.

Hargreaves, A. (1998). The emotional practice of teaching. Teaching and Teacher Education [Online], 14(8), 835-854.

Higher Education Academy (2011). UK Professional Standards Framework for Teaching and Supporting Learning in Higher Education. Higher Education Academy, Guild HE, Universities UK.

Lahtinen, A. (2008). University teachers' views on the distressing elements of pedagogical interaction. Scandinavian Journal of Educational Research [Online], 52(5), 481-493.

Liljestrom, A., Roulston, K. and deMarrais, K. (2007). There is no place for feeling like this in the workplace: Women teachers' anger in school settings. In: Schutz, P. S. and Pekrun, R. eds. Emotion in Education. [Online]. San Diego: Academic Press, pp. 275-291.

Liston, D. P. and Garrison, J. W. (2004). Teaching, Learning, and Loving: Reclaiming Passion in Educational Practice. [Online]. London, UK: RoutledgeFalmer.

Macfarlane, B. (2004). Teaching with Integrity: The Ethics of Higher Education Practice. [Online]. Hove, UK: Psychology Press.

Malcolm, J. and Zukas, M. (2001). Bridging pedagogic gaps: conceptual discontinuities in higher education. Teaching in Higher Education [Online], 6(1), 33-42.

Martin, J. R. (2004). The love gap in the educational text. In: Liston, D. and Garrison, J. eds. Teaching, Learning and Loving: Reclaiming Passion in Educational Practice. [Online]. London, UK: RoutledgeFalmer, pp. 21-34. 
Neumann, A. (2006). Professing passion: Emotion in the scholarship of professors at research universities. American Educational Research Journal [Online], 43(3), 381-424.

Noddings, N. (2013). Caring: A Relational Approach to Ethics and Moral Education. [Online]. Oakland, CA: University of California Press.

Pekrun, R., et al. (2007). The control-value theory of achievement emotions: An integrative approach to emotions in education. In: Schutz, P. and Pekrun, R. eds. Emotion in Education. [Online]. San Diego: Academic Press, pp. 13-36.

Pelias, R. J. (2004). A Methodology of the Heart: Evoking Academic and Daily Life. [Online]. Rowman Altamira.

Pleschova, G., et al. (2013). The Professionalisation of Academics as Teachers in Higher Education [Online]. European Science Foundation Position Paper. European Science Foundation. Available from: http://www.esf.org/fileadmin/Public_documents/Publications/professionalisation_a cademics.pdf

Prendergast, M. (2009). Poem is what? Poetic inquiry in qualitative social science research. International Review of Qualitative Research [Online], 1(4), 541-568.

Prinz, J. J. and Nichols, S. (2010). Moral emotions. In: Doris, J. M. ed. The Moral Psychology Handbook. [Online]. Oxford: Oxford University Press, pp. 111-146.

Puwar, N. and Sharma, S. (2012). Curating sociology. The Sociological Review [Online], 60(S1), 40-63.

Quinlan, K. M. (2016a). Developing student character through disciplinary curricula: an analysis of UK QAA subject benchmark statements. Studies in Higher Education [Online], 41(6), 1041-1054.

Quinlan, K. M. (2016b). How Higher Education Feels: Commentaries on Poems That Illuminate Emotions in Learning and Teaching. [Online]. Rotterdam, The Netherlands: Sense Publishers.

Scager, K., et al. (2017). Teacher dilemmas in challenging students in higher education. Teaching in Higher Education [Online], 22(3), 318-335. Available from: http://search.ebscohost.com/login.aspx?direct=true \&db=bri\&AN=121290611\&site =ehost-live.

Shapira-Lishchinsky, O. (2011). Teachers' critical incidents: Ethical dilemmas in teaching practice. Teaching \& Teacher Education [Online], 27(3), 648-656. Available from: http://search.ebscohost.com/login.aspx?direct=true \&db=bri\&AN=57858807\&site $=$ ehost-live. 
Sutton, R. E. (2007). Teachers' anger, frustration, and self-regulation. In: Schutz, P. S. and Pekrun, R. eds. Emotion in Education. [Online]. San Diego: Academic Press, pp. 259-274.

Trowler, P. and Cooper, A. (2002). Teaching and learning regimes: Implicit theories and recurrent practices in the enhancement of teaching and learning through educational development programmes. Higher Education Research \& Development [Online], 21(3), 221-240.

Turiel, E. (1983). The Development of Social Knowledge: Morality and Convention. [Online]. Cambridge, UK: Cambridge University Press.

van Lankveld, T., et al. (2017). Developing a teacher identity in the university context: A systematic review of the literature. Higher Education Research $\backslash \&$ Development [Online], 36(2), 325-342.

Yin, R. K. (2013). Case Study Research: Design and Methods. [Online]. Thousand Oaks, CA: Sage Publications. 